\title{
Changes of erythrocyte element status of colectomysed cancerous patients, a retrospective study
}

\author{
Kleiner D., Szilvás Á., Szentmihályi K., Süle K., Blázovics A
}

\begin{abstract}
Abstact
\end{abstract}
\section{Introduction}

Numerous surgical, radiotherapic and chemotherapic treatments as well as supportive therapies serve the quality of life, the survival and rehabilitation of cancerous patients (Boyle 2008, Millar 2012, Feng 2013).

One of the most feared side-effect is the dementia-like "chemo brain". This kind of cognitive disorder has been attached mostly to chemotherapy, but further studies revealed much more influential factors then the chemotherapeutic agent (Hurria 2007).

It is well known cognitive and neurodegenerative disorders are also attached to oxidative stress, like Alzheimer's disease, Parkinson's disease, Wilson's disease, Friedrich ataxia and prion-diseases (Ward 2014, Butterfield 2014; Singh 2010, Dusek 2014). As the redox system is in a close relation to the metal ion homeostasis, disturbances in the metabolism of elements (mostly the disregulation of $\mathrm{Cu}$ and/or $\mathrm{Fe}$ ) are also confirmed in these neurodegenerative disorders. While $\mathrm{Zn}$ serves as a neuro-co-transmitter also, its accumulation has been also observed in some neurodegenerative disorders (Braidy 2014).

In earlier clinical studies we found significant differences in metal and redox homeostasis as well as in red blood cell count (RBC), and in transmethylating ability in operated and treated colorectal and prostate cancerous patients compared with healthy controls (Blázovics 2009, Blázovics 2012, Nyirádi 2010). In different cancers the concentrations of $\mathrm{Ca}, \mathrm{Mg}$ and transition metal elements were altered significantly (Váli 2008). Elevated $\mathrm{Ca} / \mathrm{Mg}$ ratios in the erythrocytes were calculated in colorectal cancerous patients therefore this observation may connect to the higher osteoporosis frequency in female patients especially in cancerous processes (Blázovics 2009).The concentration of erythrocyte $\mathrm{Ca}$ in the patient group with prostate cancer and high PSA values was significantly lowered compared to healthy control group. Other authors also find elevated sera $\mathrm{Ca}$ concentration in patients with prostate cancer (Skinner 2009). This observation supports that in the case of prostate cancer $\mathrm{Ca}$ is mobilized from the cells and the depletion of Ca is started (Nyirádi 2010).

In animal experiment cisplatin elevated the free radical reactions in the body, although redox balance did not changed notably. The treatment increased $\mathrm{Pt}$ but lessened $\mathrm{Fe}, \mathrm{Cu}, \mathrm{Mn}, \mathrm{Mo}$ and $\mathrm{Zn}$ concentrations in the kidney, while the treatment increased plasma $\mathrm{Fe}$ and $\mathrm{Cu}$ concentrations. (Máthé 2013) According to the study the most relevant alteration was found for $\mathrm{Al}$ and $\mathrm{Pb}(\mathrm{SZ})$.

Since $\mathrm{Cu}, \mathrm{Fe}, \mathrm{Mn}, \mathrm{Zn}$ trace metal elements and $\mathrm{S}, \mathrm{Se}, \mathrm{P}$ non-metal essential elements are ubiquitous in biological system, and they play a key role in redox balance, therefore these alterations are very important in cancerous processes point of view. Enormous trace metal elements, such as $\mathrm{Fe}, \mathrm{Cu}, \mathrm{Mn}$ directly and $\mathrm{Zn}$ indirectly may catalyse the production of reactive oxygen radicals, at the same time these elements influence the antioxidant enzyme system (Szentmihályi 2014). 
Since cerebral accumulation of Al has written down in patients with Alzheimer's and Parkinson's disease, it should be also highlighted, that in a complex form this element may have prooxidant property (Kumar 2010; Exley 2004).

Therefore in this paper our aim was a retrospective element analysis to study the $\mathrm{Al}$ accumulation in patients with colorectal cancer after colectomy, hypothetized the role of $\mathrm{Al}$ in chemo brain syndrome.

\section{Materials and methods}

The 5,5'-dithiobis(2-nitrobenzoic acid) (DTNB); the 1,1-diphenyl-2-picrylhydrazyl radical (DPPH); microperoxidase and luminol was accepted from Sigma-Aldrich Co. (St. Louis; USA). Other solvents and commodities were obtained from Reanal-KER Ltd. (Budapest, Hungary).

The retrospective study was made with the data of 63 patients. Colectomysed cancerous patients $\mathrm{N}=28\left(\mathrm{~N}_{\text {male }}=15 ; \mathrm{N}_{\text {female }}=13\right.$; mean age $\left.\pm \mathrm{SD}=63.36 \pm 8.24\right)$ operated in 3 years were involved into the study. Patients of the control group $\mathrm{N}=35\left(\mathrm{~N}_{\text {male }}=16 ; \mathrm{N}_{\text {female }}=19\right.$; age $=$ $49.03 \pm 13.64)$ were outpatients. Exclusion criteria were malignancy and inflammatory bowel diseases. Additional 17 healthy volunteers from both genders were included in the study to evaluate the element contents of both cancerous and outpatient group.

\section{Sample management}

Blood samples were collected to Vacutainer Rapid Serum Tubes for serum and prepared with standard methods. For redox parameters and element analysis, blood was collected to citrate containing tubes. Plasma and erythrocyte samples were prepared by standard methods. Erythrocyte samples were determined with CHR Hemoglobin D reagent (Reagens Ltd., Hungary) and standardized to $1 \%$ hemoglobin.

White blood cell (WBC), red blood cell (RBC), haemoglobin (HGB), hematocrit (HTC), mean corpuscular volume $(\mathrm{MCV})$, mean cell haemoglobin $(\mathrm{MCH})$, mean corpuscular haemoglobin concentration (MCHC), red cell distribution (RDW), platelet (PLT) were determined by haematological automat Advia 120 (Bayer).

Carbamid, creatinin, uric acid, serum total protein, albumin, total and direct bilirubin, serum glutamic-oxaloacetic transaminase (SGOT), serum glutamic-pyruvic transaminase (SGPT), gamma-glutamyl transferase (GGT), alkaline phosphatise (ALP), C-reactive protein (CRP), albumin/globulin ratio (Alb/Glob) were determined by Roche enzymatic in vitro assays. HbA1c was measured by Variant II HPLC from BioRad, the hematological parameters.

Carcinoembryonic antigen (CEA), carbohydrate antigen 19-9 (CA 19-9), alpha-fetoprotein (AFP) tumor markers were measured with kits (LIA-mAT immunoluminometry, Budapest).

Parameters from the blood and the sera were measured by routine methods.

Redox parameters:

The free sulphydril-groups ( $\mathrm{SH}$ ) concentration in the plasma was determined with 5,5'dithiobis(2-nitrobenzoic acid) at 440nm by the Ellmann-reaction, modified by Sedlak et al. (1986). Standard was made from glutation. 
Reducing power from the plasma was determined by Oyaizu (1986) with the reduction of $\mathrm{Fe}$ III to Fe II; and measured at 700nm. The standard was made from ascorbic acid.

The hydrogen-donating (H-donating) ability in the plasma was measured by Hatano et al. (1988) with 1,1-diphenyl-2-picrylhydrazyl radical (DPPH) at $517 \mathrm{~nm}$. Inhibiting\% was determined from the controll's absorbance.

A chemiluminometric assay was adapted to Berthold Lumat 9501 luminometer to study total scavenger capacity of plasma and erythrocyte samples. $\mathrm{H}_{2} \mathrm{O}_{2} / \mathrm{OH} \bullet+$ microperoxidase + luminol system emits light in basic solution. The emission is in correlation with the with the amount of free radicals in the system, therefore it is in negative correlation with the scavenger capacity of the samples. The emitted amount of light was expressed in the logarithm on the relative light unit $(\log (\mathrm{RLU}))$ (Blázovics et al., 1999).

\section{Element analysis}

Erythrocyte samples were digested with $65 \%$ nitric acid then hydrogen peroxide. After digestion and evaporation samples were diluted to $10 \mathrm{ml}$ with bidistilled water. Inductively coupled plasma optical emission spectrometric (ICP-OES) method was applied for measuring content using a Spectro Genesis ICP-OES (Kleve, Germany) equipment. Spectro multielement and Spectrum 3D standards were used to standardize the instrument. (Szentmihályi 2014).

Statistical analysis was made with Microsoft Office Excel 2003 (Microsoft Corp., Redmond, USA) and Statistica 11 (StatSoft Inc., Tulsa, USA) programs. Shapiro-Wilks test was used to verify the normal distribution. If data had normal distribution, Student's t-test for independent samples was used, if they had non-parametric, or F-test was significant Mann-Whitney U-test was used distribution. To study element contents an additional healthy group was also tested. If data had normal distribution and Levene-test was not significant, comparison was made with ANOVA and Fischer's LSD test, on the other hand Kruskal-Wallis ANOVA and multiple comparasions were made. Significance level was $\mathrm{p}<0.01$.

\section{Permission number: TUKEB 167/1997, 15/2004 and IKEB 3944/2004.}

\section{Results}

There were no significant difference between tumor markers, and they were in the normal range in general. In some cancerous patients the values were higher, because the taking of the applied blood was too close too their operation, but in some cases of the outpations the data were also out of the normal range. These outpatients belonged to gastrointestinal disease groups, and several patients had liver diseases.

In the cancerous patients the interquartile range for CEA was $1.15-4.46 \mathrm{ng} / \mathrm{ml}$, in nontumorous patients it was $0.85-1.83 \mathrm{ng} / \mathrm{ml}$, respectively (normal range: $0.8-2.5 \mathrm{ng} / \mathrm{ml}$ ). For CA 19-9 interquartile range for cancerous patients was $5.10-26.0 \mathrm{U} / \mathrm{ml}$ (normal range < 33 $\mathrm{U} / \mathrm{ml}$ ); and for AFP it was $1.96-3.04 \mathrm{ng} / \mathrm{ml}$ (normal range: $0.5-5.5 \mathrm{ng} / \mathrm{ml}$ ), respectively. In non-tumorous patients interquartile range was $3.6-7.8$ at CA $19-9$ and $1.76-4.65 \mathrm{ng} / \mathrm{ml}$ at AFP.

Routine laboratory parameters showed no significant differences, except RDW (Fig. X.), which was significantly higher in the cancerous group ( $<<0.001)$; ALP (Fig. Y.) was also 
markedly higher in this group $(\mathrm{p}=0.004)$; but albumin/globulin ratio (Fig. Z.) was lower in the cancerous patients $(\mathrm{p}<0.001)$.

At the redox measurement only slight differences could have been observed, without any significance. On the other hand it should be noticed by the mean values that free $\mathrm{SH}$ concentration, reducing power as well as plasma and erythrocyte scavenger capacity was better in the cancerous patients, only $\mathrm{H}$-donating ability was lower in this group, compared to the control outpatients.

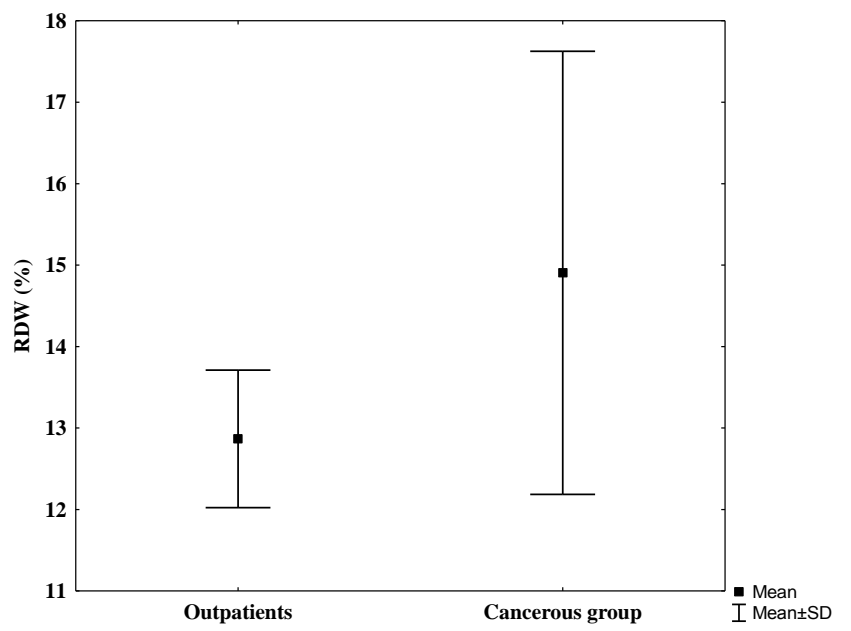

Figure X. Red blood cell distribution width (RDW) in the cancerous and control group ( $<$ $0.001)$.

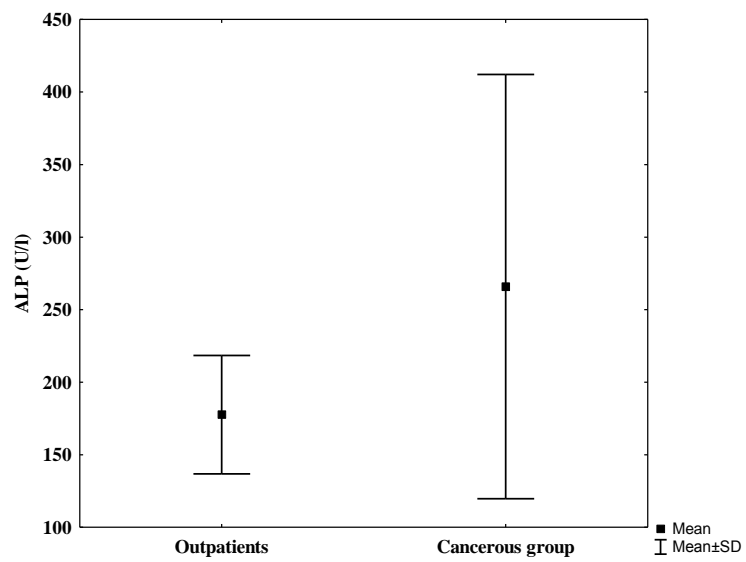

Figure Y. alkaline phosphatase (ALP) concentration in the cancerous and control group $(\mathrm{p}=$ 0.004). 


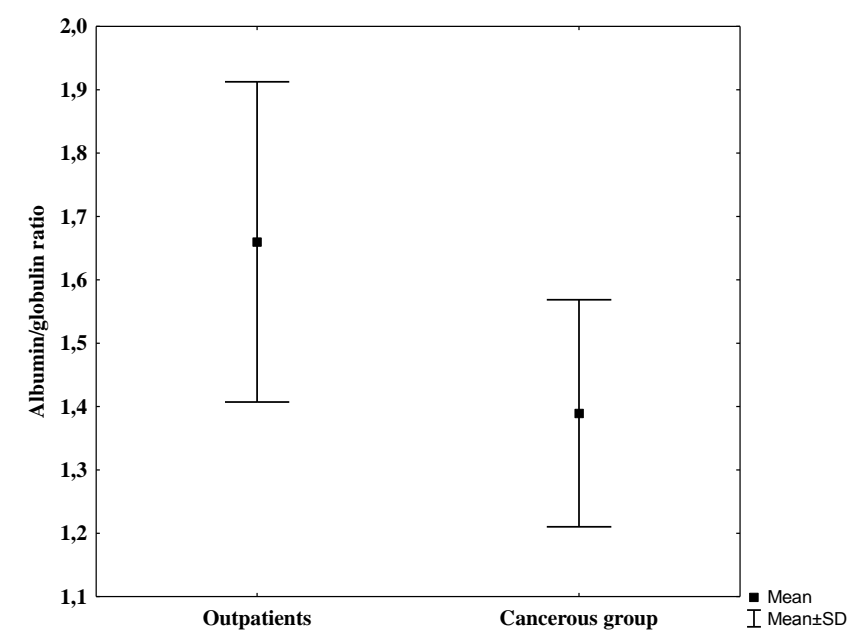

Figure Z. The albumin/globulin ratio in the cancerous and control group $(\mathrm{p}<0.001)$.

\begin{tabular}{|c|c|c|c|c|}
\hline & $\begin{array}{l}\text { healthy controls } \\
(\mathrm{N}=17)\end{array}$ & $\begin{array}{l}\text { outpatients } \\
(\mathrm{N}=35)\end{array}$ & $\begin{array}{c}\text { cancerous group } \\
(\mathrm{N}=28)\end{array}$ & \\
\hline & Mean \pm SD & Mean \pm SD & Mean \pm SD & \\
\hline $\mathrm{Al}(\mathrm{ppm})$ & $0.413 \pm 0.208$ & $0.859 \pm 1.925$ & $1.455 \pm 1.900$ & \\
\hline $\mathrm{Cu}(\mathrm{ppm})$ & $0.065 \pm 0.043$ & $0.034 \pm 0.032$ & $0.066 \pm 0.078$ & \\
\hline $\operatorname{Mg}(\mathrm{ppm})^{*}$ & $1.443 \pm 0.401$ & $1.624 \pm 0.360$ & $1.858 \pm 0.380$ & $\mathrm{p}=0.002$ \\
\hline $\mathrm{Mn}(\mathrm{ppm})$ & $0.010 \pm 0.007$ & $0.012 \pm 0.010$ & $0.014 \pm 0.009$ & \\
\hline $\mathrm{Zn}(\mathrm{ppm})^{* * *}$ & $0.450 \pm 0.138$ & $0.376 \pm 0.119$ & $0.543 \pm 0.253$ & $\mathrm{p}=0.001$ \\
\hline $\mathrm{Ca}(\mathrm{ppm})^{* * *}$ & $1.650 \pm 0.464$ & $3.371 \pm 2.667$ & $3.278 \pm 2.135$ & $\mathrm{p}<0.001$ \\
\hline $\mathrm{P}(\mathrm{ppm})^{* * * *}$ & $9.205 \pm 4.198$ & $18.074 \pm 15.287$ & $29.826 \pm 12.752$ & $\mathrm{p}<0.001$ \\
\hline $\mathrm{S}^{\dagger}(\mathrm{ppm})^{* * *}$ & $35.474 \pm 5.698$ & $60.799 \pm 18.071$ & $73.076 \pm 28.126$ & $\mathrm{p}<0.001$ \\
\hline $\mathrm{Fe}(\mathrm{ppm})^{*, * *}$ & $19.498 \pm 5.828$ & $28.425 \pm 5.969$ & $32.572 \pm 7.278$ & $\mathrm{p}<0.001$ \\
\hline
\end{tabular}

Table N

Element contents in the three different groups.

${ }_{* *}^{*} \mathrm{p}<0.01$ between healthy controls and cancerous patients

${ }_{* * *}^{* *}<0.01$ between healthy controls and outpatients

${ }^{* * * *} \mathrm{p}<0.01$ between outpatients and cancerous patients

${ }^{\dagger} \mathrm{N}_{\text {healthy control }}=10$

The main question of this study was whether or not the element concentrations of the erythrocytes show alterations in cancer-treated patients, compared to internal medicinal patients without known tumor or irritable bowel disease in their history or healthy subjects (Table N). There were no significant differences in the $\mathrm{Al}, \mathrm{Cu}$ and $\mathrm{Mn}$ concentrations, but the $\mathrm{Ca}\left(\mathrm{p}_{\text {Kruskal-Wallis ANOVA }}<0.001\right)$, the $\mathrm{S}$ ( $\left.\mathrm{p}_{\text {Kruskal-Wallis ANOVA }}<0.001\right)$ and the Fe $\left(\mathrm{p}_{\text {Kruskal-Wallis }}\right.$ ANOVA $<0.001)$ content were significantly lower in healthy group compared to outpatients 
(healthy group/outpatients: $\left.\mathrm{p}_{\mathrm{Ca}}<0.001 ; \mathrm{p}_{\mathrm{S}}<0.001 ; \mathrm{p}_{\mathrm{Fe}}<0.001\right)$ and cancerous patients (healthy group/cancerous group: $\left.\mathrm{p}_{\mathrm{Ca}}<0.001 ; \mathrm{p}_{\mathrm{S}}<0.001 ; \mathrm{p}_{\mathrm{Fe}}<0.001\right)$ without marked differences between the outpatients and cancerous patients. In healthy patients only 10 were proper for measure the $\mathrm{S}$ content. $\mathrm{Mg}$ concentration was slightly elevated in the group of the outpatients but it was significantly higher in the cancerous group compared to healthy group ( $\mathrm{p}_{\mathrm{ANOVA}}=0.002$; $\mathrm{p}<0.001$ ). The highest concentration of $\mathrm{Zn}$ and $\mathrm{P}$ were detected in the tumorous group ( $\mathrm{Zn}$ : $\mathrm{p}_{\text {Kruskal-Wallis ANOVA }}=0.001$; outpatients/cancerous group: $\mathrm{p}<0.001 ; \mathrm{P}: \mathrm{p}_{\text {Kruskal-Wallis ANOVA }}=0.001$; healthy group/outpatients and healthy group/cancerous group: $\mathrm{p}<0.001$ ).

The highest mean values of the element contents except $\mathrm{Ca}$ concentration were recorded in the cancer-treated patients, however $\mathrm{Al}$ should be highlighted. An upper limit of $\mathrm{Al}$ concentration has been counted from the mean value and standard deviation of the healthy group (upper limit=mean $+\mathrm{SD}=0.621 \mathrm{ppm}$ ). At the healthy group only $18 \%$ of the subjects, at the outpatients $34 \%$ of the patients, but in the cancer treated group $54 \%$ of the patients had higher value than the latter maximum. The mean value of this group was 1.7 times higher than the outpatients mean value and 3.5 times higher than the mean of the healthy controls.

One tumor-treated patient had extremely high CEA $(550 \mathrm{ng} / \mathrm{ml})$ and needed further monitoring. In this case a prominently high, more than $8.0 \mathrm{ppm} \mathrm{Al}$ concentration was also detected. This patient also had higher values than the normal range in platelet number, creatinin, GGT and ALP level and lower than normal HGB, HTC, MCV, MCH, MCHC values, but gallstones were detected as well, that were associated with inadequate liver functions.

There was a patient at the non-cancerous group with extremely elevated Al concentration (10.89 ppm). In this person the pathologically high GGT value was also visible, but only uric acid level was higher then the normal value, which is in agree with the known alcoholism.

\section{Discussion}

The significantly higher RDW, which may be a biomarker of several cancer ( Seretis 2013) is in consensus with Spell and coworkers (2004), and suggests that tumorous patients may have disturbed Fe homeostasis or already have anemia. The non-significant changes in the other hematologic parameters are in correlation with this literature, while chemotherapy may increases the risk of high MCV values, but in this case it does not changed significantly, and only in a few cases were higher than the normal value (Wenzel 2003; De La Cruz 2004). Deviations in hematologic parameters can be the sign of anemia, which is a common but serious case in cancers, therefore many treatments were evolved to resolve it, but only recent studies revealed, that in some cases the low methylation inhibited the synthesis of the haemoglobin (Hassan 2013; Blázovics 2008). Methyl pool is significantly lowered in cancerous patients, therefore haemoglobin biosynthesis is inhibited without free methyl group. Methyl donors are produced partly by enzymatic demethylation of some N-, S-, and Omethylated compounds. This malformation ends up in protoporphyrin-Zn incorporation to the haemoglobin, but while at prostate cancerous patients $\mathrm{Zn}$ depletion was found in our study excess $\mathrm{Zn}$ can be observed in erythrocyte samples of cancerous patients. The notably high $\mathrm{Zn}$ concentration in our study is in consensus with the idea of Zn-protoporphyrin incorporation to haemoglobin and supports the idea, that these patients have at least mild anemia (Blázovics 2012).

The cancer related inflammation and malnutrition (Bovio 2009) together suggest a lower albumin and higher proinflammatory protein concentration (Ionescu 2013). It should be 
mentioned, that the tumor markers are also counted in the globulin concentration of the albumin/globulin ratio, while they are recently higher in cancerous patients (Azab 2013). All in all it was expected, that the albumin/globulin ratio has been considerably lower in the cancerous patients. It suggests the adverse processing in the nutrition which further influences the outcomes of the surgical treatment, but further may influence the efficacy of the whole treatment too (Ionescu 2013; Boyle 2008).

The elevated ALP activity in the blood was also expectable (Saif 2005). While the data of the patients in this study were generally in the normal range $(100-290 \mathrm{U} / \mathrm{l})$, Saif and coworkers suggested $160 \mathrm{U} / 1$ for cutoff point. It may be a better marker for liver metastasises. In this case most of our participants should be supervised more often than the regular protocols advices.

In the redox parameters, only slight differences were visible, and most of them were better in the cancerous patients. While only the H-donating activity of the plasma, was better in noncancerous group, higher free SH level and reducing power were measured in the plasma, and lower light emission was detected with the chemiluminometric method in the plasma as well as in the erythrocytes of cancerous patients. The inducible chemiluminescence shows the level of free radicals, and is in a negative correlation with the scavenger capacity. It was unexpected, that redox parameters were as good as in the non-cancerous group, because numerous studies show, that antioxidant vitamins or other antioxidant parameters are significantly lessened in colorectal cancers (Beno 2000; Hronek 2000; Koçer and Nazıroğlu 2013; Blázovics 2008). These results support the idea of the change to a healthier life, as a result of good medical management, but on the other hand, in this study the control group had also gastrointestinal problems, and some of them may have drinking disorders.

While the concentrations of almost all elements were higher in the cancerous patients, it is not clear if metabolic element accumulation, higher level of cell death, or other mechanism can be observed. The significantly higher $\mathrm{P}$ level in cancerous patients compared to the other two groups maybe the sign of cell death, because hyperphosphatemia is also a signal of the rare but life threatening case, the tumor lysis syndrome (Kim 2014). The importance of $P$ concentration is discussed in surgical cases, and in the future may become a crucial prognostic factor (Ye 2013).

$\mathrm{Zn}$ concentration has changed diversely in the two patient groups. Its concentration has been lowered in the outpatients, but elevated in the cancerous group, causing significant difference between the two patient groups. The elevated $\mathrm{Zn}$ concentration may also suggested by some already reported cases, that determined elements in the blood (Shenberg 1995) and measured increased urinary excretion (Melichar 1994; Hronek 2000). In the study of Shenberg, the increased blood $\mathrm{Cu}$ level in cancerous patients could be also noticed, but in their case the $\mathrm{Fe}$ content was lowered in the cancerous patients. Elevated $\mathrm{Cu}$ level was also suggested by two other studies (Beno 2000; Gupta 1993).

Only scarce data could be found about $\mathrm{Al}$ contents in studies about colorectal tumors, but Lavilla et al. (2009) has found elevated $\mathrm{Al}$ and essential element content in cancerous tissues while compared the healthy to the cancerous tissues in 38 colorectal cancerous patients. This study can confirm the elevated Al-content in our study. One cancerous patient had more than $8.0 \mathrm{ppm} \mathrm{Al} \mathrm{concentration,} \mathrm{while} \mathrm{the} \mathrm{mean} \mathrm{value} \mathrm{was} \mathrm{about} 1.46 \mathrm{ppm}$ still in the cancerous group. It was also associated with poor prognostic factors, like anemia-like symptoms, hepatic disorders, maybe a liver metastasis that the high CEA and ALP value can predict. As the highest $\mathrm{Al}$ concentration in the non-cancerous group was also associated with high GGT 
value, it may also confirm the hepatotoxicity of $\mathrm{Al}$ (Shati 2010). On the other hand the known alcoholism increases GGT parameter too and the Al accumulation maybe just worsens the hepatic disorder. These results raise the question if the high $\mathrm{Al}$ concentration is the inducer or the result of hepatic disorders and further worsens the function of the liver.

On the other hand, it is well known, that elevated element concentrations, for instance $\mathrm{Al}$; $\mathrm{Fe}$; $\mathrm{Cu}$; $\mathrm{Zn}$ level can cause disturbances in the redox homeostasis of healthy tissues, for example in neurons as it has been proven in many studies about Alzheimer's, Parkinson's or Wilson's disease, Friedrich ataxia and prion-diseases (Ward 2014, Butterfield 2014; Singh 2010, Dusek 2014; Braidy 2014). Since the chemotherapy associated cognitive impairment is not clearly understood yet, but oxidative stress has been confirmed in these cases, researches about associations with the element contents are necessary (Hurria 2007; Butterfield 2014). Taken together our study revealed the elevated source of redox related elements in colorectal cancer treated patient, in particular the the $\mathrm{Al}$ content, the significantly higher $\mathrm{Zn}$ concentration compared to outpatients, and Fe content compared to healthy subjects that may be factors in "chemo-brain" or other oxidative stress related disorders in cancer and/or chemotherapy.

\section{Conclusion}

In this retrospective study colorectal cancerous patients were compared to internal medicinal outpatients. Routine laboratory parametesr were generally in the normal range and only RDW, ALP and albumin/globulin ratio differed significantly. There were no significant differences in the redox parameters too. The main question was whether the cancerous state differ the element contents of the erythrocytes, therefore an additional healthy group was added. The measured elements ( $\mathrm{Al}, \mathrm{Cu}, \mathrm{Mg}, \mathrm{Mn}, \mathrm{Zn}, \mathrm{Ca}, \mathrm{P}, \mathrm{S}$ and $\mathrm{Fe}$ ) were in a higher concentration in cancerous patients compared to healthy subjects. All measured elements, except $\mathrm{Ca}$ were similarly in a higher concentration in cancerous patients compared to outpatients. All in all an element accumulation can be observed in the cancerous state. The higher amount of $\mathrm{Al}, \mathrm{Cu}, \mathrm{Zn}$ and $\mathrm{Fe}$ should be highlighted, as the dysregulation of these elements are well known features in neurological disorders, like Alzheimer's, Parkinson's or Wilson's disease, Friedrich ataxia and prion-diseases. This result suggests, that "chemobrain" and other redox system related disorders in cancerous state and/or under chemotherapy may be related to disturbed element homeostasis as well.

SUPPORT: ETT-012/2006.

Authors express their thanks to Mrs. Sarolta Bárkovits, Edina Pintér and Erzsébet Bíró for their excellent technical assistances.

\section{References}

Beno I, Klvanová J, Magálová T, Brtková A.: Blood levels of natural antioxidants in gastric and colorectal precancerous lesions and cancers in Slovakia. Neoplasma. 2000;47(1):37-40.

Blázovics A., Kovács Á., Lugasi A., Hagymási K., Bíró L., Fehér J.: Antioxidant defence in erythrocytes and plasma of patients with active and quiescent Crohn's disease and ulcerative colitis: A chemiluminescent study, Clin. Chem., 1999a, 45, 6, 895-896. 
Blázovics A, Szilvás A, Székely G, Tordai E, Székely E, Czabai G, Pallai Z, Sárdi E.: Important bioactive molecules of erythrocytes in colorectal cancer patients after colectomy. Open Med Chem J. 2008.2:6-10.

Blázovics A, Szilvás Á, Sárdi É, Székely E, Bekő G, Szentmihályi K.: Metal homeostasis in colorectal cancer patients after colectomy. In: Szilágyi M, Szentmihályi K (Eds.): Trace Elements in the Food Chain: Vol. 3: Deficiency or Excess of Trace Elements in the Environment as a Risk of Health. 490 p. 2009.05.21-2009.05.23. Budapest: Working Committee on Trace Elements of the Complex Committee of the HAS - Institute of Materials and Environmental Chemistry of the HAS, 2009. pp. 41-45. (ISBN:978-963-7067-19-8)

Blázovics A, Nyirády Péter, Romics Imre, Szücs Miklós, Horváth András, Szilvás Ágnes, Székely Edit, Szentmihályi Klára, Bekő Gabriella, Sárdi Éva: How Can Cancer-Associated Anemia Be Moderated with Nutritional Factors and How Do Beta Vulgaris L. Ssp. Esculenta Var. Rubra Modify the Transmethylation Reaction in Erythrocytes in Cancerous Patients?, Anemia, Dr. Donald Silverberg (Ed.), ISBN: 978-953-51-0138-3, InTech. (2012) DOI: 10.5772/30096. Available from: http://www.intechopen.com/books/anemia/how-can-cancerassociated-anemia-be-moderated-with-nutritional-factors-and-how-do-beta-vulgaris-l-ss

Bovio G, Montagna G, Bariani C, Baiardi P.: Upper gastrointestinal symptoms in patients with advanced cancer: relationship to nutritional and performance status. Support Care Cancer. 2009.17(10):1317-24.

Boyle, P., Levin, B.: World Cancer Report 2008. International Agency for Research on Cancer (IARC). Lyon. 2008. pp. 62-95.

Braidy N1, Poljak A2, Marjo C3, Rutlidge H3, Rich A3, Jayasena T1, Inestrosa NC4, Sachdev P5.: Metal and complementary molecular bioimaging in Alzheimer's disease.Front Aging Neurosci. 2014. 6:138.

Butterfield DA.: The 2013 SFRBM discovery award: Selected discoveries from the butterfield laboratory of oxidative stress and its sequela in brain in cognitive disorders exemplified by Alzheimer disease and chemotherapy induced cognitive impairment. Free Radic Biol Med. 2014. 74C:157-174.

Chen CI, Miser J, Kuan CF, Fang YA, Lam C, Li YC.: Critical laboratory result reporting system in cancer patients. Comput Methods Programs Biomed. 2013 Jul;111(1):249-54

De La Cruz L., Albero A., Barros M. M., Moreno A., Virizuela J. A., Sánchez M. J., De Toro R., Portillo M., Toral J. C. and Duque A.: A multicenter sequential phase IV study of oxaliplatin (Oxa) and capecitabine (Cap) followed by irinotecan (Iri) and capecitabine in first line advanced colorectal cancer (ACC). Preliminary results. J Clin Oncol (Meeting Abstracts), 2004 ASCO Annual Meeting Proceedings (Post-Meeting Edition). Vol 22. 14S. 2004: 3652

Dusek P, Roos PM, Litwin T, Schneider SA, Flaten TP, Aaseth J.: The neurotoxicity of iron, copper and manganese in Parkinson's and Wilson's diseases. J Trace Elem Med Biol. 2014. [Epub ahead of print] 
Exley C.: The pro-oxidant activity of aluminum. Free Radic Biol Med. 2004. 36(3):380-7.

Farhangi MA, Keshavarz SA, Eshraghian M, Ostadrahimi A, Saboor-Yaraghi AA.: White blood cell count in women: relation to inflammatory biomarkers, haematological profiles, visceral adiposity, and other cardiovascular risk factors. J Health Popul Nutr. 2013 Mar;31(1):58-64.

Ferlay J, Soerjomataram I, Ervik M, Dikshit R, Eser S, Mathers C, Rebelo M, Parkin DM, Forman D, Bray, F.: GLOBOCAN 2012 v1.0, Cancer Incidence and Mortality Worldwide: IARC CancerBase No. 11 [Internet]. Lyon, France: International Agency for Research on Cancer; 2013. Available from: http://globocan.iarc.fr

Gupta SK, Shukla VK, Vaidya MP, Roy SK, Gupta S.: Serum and tissue trace elements in colorectal cancer. J Surg Oncol. 1993;52(3):172-5.

Hamilton W, Lancashire R, Sharp D, Peters TJ, Cheng KK, Marshall T.: The importance of anaemia in diagnosing colorectal cancer: a case-control study using electronic primary care records. Br J Cancer. 2008 Jan 29;98(2):323-7.

Hatano T., Kagawa H., Yasuhara T., Okuda T.: Two new flavonoids and other constituents in licore root: their relative astringency and radical scavenging effects, Chem. Pharm. Bull., 1988, 36, 2090-2097.

Hronek M, Zadak Z, Solichova D, Jandik P, Melichar B.: The association between specific nutritional antioxidants and manifestation of colorectal cancer. Nutrition. 2000 Mar;16(3):189-91.

Hurria A, Somlo G, Ahles T.: Renaming "chemobrain". Cancer Invest. 2007. 25(6):373-7.

Ionescu D, Tibrea C, Puia C.: Pre-operative hypoalbuminemia in colorectal cancer patients undergoing elective surgery - a major risk factor for postoperative outcome. Chirurgia (Bucur). 2013;108(6):822-8.

Jemal A, Bray F, Center MM, Ferlay J, Ward E, Forman D.: Global cancer statistics. CA Cancer J Clin. 2011. 61(2):69-90.

Lavilla I, Costas M, Miguel PS, Millos J, Bendicho C.: Elemental fingerprinting of cancerous and adjacent non-cancerous tissues from patients with colorectal cancer using ICP-MS, ICPOES and chemometric analysis. Biometals. 2009.22(6):863-75.

Liu Hui, Wang Ge-ge, Li Zhiyue, Gu Yanan.: Association Analysis of Biological Variations in Different Routinely Measured Biochemical Parameters in Healthy Subjects. (2009) LabMedicine, 40, 474-477.

Kim HD, Ha KS, Woo IS, Jung YH, Han CW, Kim TJ.: Tumor lysis syndrome in a patient with metastatic colon cancer after treatment with 5-fluorouracil/leucovorin and oxaliplatin: case report and literature review. Cancer Res Treat. 2014 Apr;46(2):204-7. 
Koçer M, Nazıroğlu M.: Effects of 5-fluorouracil on oxidative stress and calcium levels in the blood of patients with newly diagnosed colorectal cancer. Biol Trace Elem Res. 2013 Dec;155(3):327-32.

Melichar B, Jandík P, Malír F, Tichý M, Bures J, Mergancová J, Voboril Z.: Increased urinary zinc and copper excretion in colorectal cancer. $\mathrm{J}$ Trace Elem Electrolytes Health Dis. 1994;8(3-4):209-12.

Mezzetti A1, Pierdomenico SD, Costantini F, Romano F, De Cesare D, Cuccurullo F, Imbastaro T, Riario-Sforza G, Di Giacomo F, Zuliani G, Fellin R.: Copper/zinc ratio and systemic oxidant load: effect of aging and aging-related degenerative diseases. Free Radic Biol Med. 1998 Oct;25(6):676-81.

Millar H, Davison J.: Nutrition education for osteoporosis prevention in men with prostate cancer initiating androgen deprivation therapy. Clin J Oncol Nurs. 2012. 16(5):497-503.

Oyaizu M.: Studies on products of browning reaction prepared from glucosamine, Jpn. J. Nutr., 1986, 44, 307-315.

Skinner, H.G., Schwartz, G.G. 2009. A prospective study of total and ionized serum calcium and fatal prostate cancer. Cancer Epidem. Biomark Prev. 18, 575-8.

Saif MW, Alexander D, Wicox CM.: Serum Alkaline Phosphatase Level as a Prognostic Tool in Colorectal Cancer: A Study of 105 patients. J Appl Res. 2005;5(1):88-95.

Sedlak J., Lindsay R.H.: Estimation of total protein bound and non protein sulfhydryl groups in tissues with Ellmann's reagent, Anal. Biochem. Biophys., 1985, 25, 192-205.

Shati AA, Alamri SA.: Role of saffron (Crocus sativus L.) and honey syrup on aluminuminduced hepatotoxicity. Saudi Med J. 2010. 31(10):1106-13.

Shenberg C, Feldstein H, Cornelis R, Mees L, Versieck J, Vanballenberghe L, Cafmeyer J, Maenhaut $\mathrm{W} .: \mathrm{Br}, \mathrm{Rb}, \mathrm{Zn}, \mathrm{Fe}, \mathrm{Se}$ and $\mathrm{K}$ in blood of colorectal patients by INAA and PIXE. J Trace Elem Med Biol. 1995.9(4):193-9.

Singh N1, Singh A, Das D, Mohan ML.: Redox control of prion and disease pathogenesis. Antioxid Redox Signal. 2010. 1;12(11):1271-94.

Spell DW, Jones DV Jr, Harper WF, David Bessman J.: The value of a complete blood count in predicting cancer of the colon. Cancer Detect Prev. 2004;28(1):37-42.

Szentmihályi K, May Z, Szénási G, Máthé C, Sebestény A, Albert M, Blázovics A.: Cisplatin administration influences on toxic and non-essential element metabolism in rats. $\mathrm{J}$ Trace Elem Med Biol. 2014. 28(3):317-321.

Svobodova S1, Topolcan O, Holubec L Jr, Levy M, Pecen L, Svacina S.: Parameters of biological activity in colorectal cancer. Anticancer Res. 2011.31(1):373-8.

Tefferi A.: Anemia in adults: a contemporary approach to diagnosis. Mayo Clin Proc. 2003 Oct;78(10):1274-80. 
Váli, L., Hahn, O., Kupcsulik, P. et al. 2008. Oxidative stress with altered element content and decreased ATP level of erythrocytes in hepatocellular carcinoma and colorectal liver metastases. Eur. J. Gastroent. Hepatol. 20, 393-398.

Voudoukis E, Karmiris K, Oustamanolakis P, Theodoropoulou A, Sfiridaki A, Paspatis GA, Koutroubakis IE.: Association between thrombocytosis and iron deficiency anemia in inflammatory bowel disease. Eur J Gastroenterol Hepatol. 2013 Oct;25(10):1212-6.

Ward RJ, Zucca FA, Duyn JH, Crichton RR, Zecca L.: The role of iron in brain ageing and neurodegenerative disorders. Lancet Neurol. 2014. 13(10):1045-1060.

Wenzel C, Mader RM, Steger GG, Pluschnig U, Kornek GV, Scheithauer W, Locker GJ.: Capecitabine treatment results in increased mean corpuscular volume of red blood cells in patients with advanced solid malignancies. Anticancer Drugs. 2003 Feb;14(2):119-23.

Yang MH, Rampal S, Sung J, Choi YH, Son HJ, Lee JH, Kim YH, Chang DK, Rhee PL, Kim JJ, Rhee JC, Chun HK, Guallar E, Cho J.: The association of serum lipids with colorectal adenomas. Am J Gastroenterol. 2013.108(5):833-41.

Ye Z, Palazzo JP, Lin L, Lai Y, Guiles F, Myers RE, Han J, Xing J, Yang H.: Postoperative hyperphosphatemia significantly associates with adverse survival in colorectal cancer patients. J Gastroenterol Hepatol. 2013 Sep;28(9):1469-75.

Yeom CH, Jung GC, Song KJ.: Changes of terminal cancer patients' health-related quality of life after high dose vitamin C administration. J Korean Med Sci. 2007. 22(1):7-11.

Zaribaf F, Entezari MH, Hassanzadeh A, Mirzaian S.: Association between dietary iron, iron stores, and serum lipid profile in reproductive age women. J Educ Health Promot. 2014.3:15. 